\title{
'You Don't Know How Lucky You Are to Be Here!': Reflections on Covert Practices in an Overt Participant Observation Study
}

\author{
by John S. McKenzie \\ University of Aberdeen \\ Sociological Research Online, Volume 14, Issue 2, \\ $<$ http://umw. socresonline.org.uk/14/2/8.html> \\ doi:10.5153/sro. 1925
}

Received: 2 Mar 2009 Accepted: 25 May 2009 Published: 30 May 2009

\begin{abstract}
There has been a tendency in sociology to see covert and overt roles of social researchers in participant observation studies as opposites. This is both in terms of the researcher role and the surrounding ethics, with the overt researcher role being seen as fundamentally more ethical than the covert participant observer. However, Calvey (2008) alleged that covert practices often remain unreported in overt accounts. The purpose of this paper is therefore to address this issue through reflections on my own research experience. Drawing on my research with the contemporary spiritual milieu in Scotland, I will argue that the covert and overt roles are far from opposites and should be seen as part of a continuum. The moral high ground attributed to overt research is often questionable and most overt studies will employ covert practices. It will therefore be argued that decisions regarding the role of the participant observer should be grounded in the intellectual contemplation of specific research situations, including ethical considerations, rather than condemning sound social enquiry on the misguided basis that overt research is always superior to covert studies because of its ethical standards. In conclusion it will be argued that all researchers have a responsibility to reflect honestly upon their research experience as part of wider reflexive turn in social research.
\end{abstract}

\section{Keywords: Participant Observation; Ethics; Covert Research; Overt Research; Informed Consent; Researcher Role; Field Relations; Reflexivity}

\section{Introduction}

1.1 Despite a long history of debate of ethics in participant observation studies, the prevailing culture within the field of sociology tends to view covert research as far more unethical than overt studies (Bulmer, 1982a; Warwick, 1982; Shils, 1982). I have heard of researchers being in danger of failing their $\mathrm{PhD}$ due to the adoption of a covert role in their research and of journal editors that decline articles derived from covert research without considering the research situation. Until I undertook my own doctoral research this is a stance that I would have adopted and upheld with some indignation against those that transgressed this ethical boundary and compromised the integrity of the discipline (Warwick, 1982).

1.2 However, the realities of the research field were more complicated than I imagined. Adopting a strictly overt approach would have been almost impossible and would have crippled my study. Therefore to proceed I had to compromise and it soon became clear that the ethical high-ground of the overt researcher was far shakier than attitudes to overt and covert researcher roles seemed to reflect. Ultimately, to claim that my research was wholly overt would coincide with Calvey's (2009:909) argument that covert practices are 'routinely glossed over in sanitized overt accounts'.

1.3 The purpose of this paper is to therefore reflexively explore ethical considerations in a supposedly overt participant observation study. Most commentaries regarding the covert practices in overt studies appear to come from researchers trying to provide justification for undercover research. In this paper I am not going to try to justify covert practices per se but make an attempt to remove the gloss (Calvey, 2009) and reflect frankly on the covert practices in my overt study.

1.4 In this paper I will begin by outlining what is meant by participant observation and identify the current British Sociological Association (BSA) ethical guidelines for the participant observer. Secondly, I will show, with reference to my own research, that in many ways the overt researcher role does not always ensure ethical integrity and that most research projects will involve a degree of covertness. This will be illustrated through a discussion of informed consent, the researcher role and field relations. It will consequently be 
argued that the ethical status of the participant observer role should be governed more by the specifics of the research situation under study rather than the over-generalization that overt participant observation is always more ethical than covert. In conclusion, I will call for a more rigorous reflection on covert practices in overt participant observation studies as part of the reflexive turn in sociology to allow for a more informed analysis of the ethical considerations in participant observation studies.

\section{Participant Observation}

2.1 One of the purposes of my research into the contemporary spiritual milieu ${ }^{[1]}$ in Scotland was to capture the world of those who populate the milieu as they perceive it. In order to do this an ethnographic methodology was adopted as this approach allows the researcher to 'think oneself into the perspective of the members, an empathetic process Weber called Verstehen' (Fielding, 1993:157). Karen O'Reily (2005:84) explains:

Ethnographic research is a special methodology that suggests we learn about people's lives from their own perspective and from within the context of their lived experience. This involves not only talking to them and asking questions but also learning from them by observing them, participating in their lives, and asking questions that relate to the daily life experience as we have seen and experienced it.

2.2 The main method of collecting data in an ethnographic study is participant observation (Atkinson et al, 2007) and this is a particularly powerful research tool because it allows the researcher to gain insight into the meaning of the day-to-day lives of the research subjects: 'Any group of persons develop a life of their own that becomes meaningful, reasonable and normal once you get close to it...and a good way to learn about any of these worlds is to submit oneself in the company of the members, to the daily round of petty contingencies to which they are subject' (Goffman, 1961: ix-x).

2.3 Four levels of participant observation have been identified:

- Complete participant - covert, full participation.

- Participant-as-observer - overt, full participation.

- Observer-as-participant - overt, minimum participation.

- Complete observer - overt, minimum participation (Brewer, 2000:84).

2.4 However, Brewer (2000:84) points out 'These distinctions are at best ideal types for in practice the overtcovert distinction is a continuum with different degrees of openness, and the roles developed in the field vary with time and location'. Nonetheless the adoption of a particular role requires careful consideration. The intimate relationship between the researcher and the field raises important ethical concerns and places a huge responsibility on those conducting research to protect the integrity of the discipline (Brewer, 2000:89). Thus ethics are a particularly paramount concern for the participant observer.

\section{Ethics}

3.1 In conducting social research, the researcher may endeavour to search for truth but also has the responsibility of protecting the rights and integrity of the human beings under examination (Bulmer, 1982a:3). Warwick (1982:42) argues that social researchers should respect human freedom, defined as 'the capacity, opportunity and incentive to make reflective choices and to act on these choices'. These ethical issues become increasingly pertinent when covert methods of participant observation are used (Brewer, 2000; Bulmer, 1982a).

3.2 Historically much research has been carried out covertly in order to enhance likelihood of access and to avoid issues of the presence of a researcher affecting the behaviour of those being observed (Holdaway, 1982; Humphreys, 1970; Rosenhan, 1982; Wallis, 1976). However, ethical considerations have challenged this position: 'Much of the ethical debate in Britain has revolved around the desirability of covert methods of data collection, almost exclusively that of covert observation' (Brewer, 2000:89). Similarly Laine (2000:349) points out that ethics committees seem to concentrate on the principle of informed consent and the dubious nature of covert methods.

3.3 Consequently, some covert studies have been discredited. For example, the covert study of homosexual activities in public toilets in the 1960's by Laud Humphreys has been highly criticised because of the unethical nature of the covert methods of data collection used (Warwick, 1982:50) and his PhD was later rescinded. Shils (1982:131) adopts a very strict line with regard to the use of covert methods:

It is wrong for an inquirer ostensibly to take up membership in a community with the intention of conducting a sociological inquiry without making it plain that that is what he is doing. His self-disclosure might occasionally hamper research he is conducting, but the degree of injury 
suffered does not justify the deviation from straightforwardness implied by withholding his true intentions.

3.4 Other researchers have been willing to employ covert methods in some situations but placed limitations on the degree to which they were willing to deceive. For example, Roy Wallis (1977:7), in his study of Scientologists, felt unable to continue with his covert participation on a course open to the public when, after a few days, it became clear that he would have to lie about his beliefs and involvement with the group. He later explained 'I was not prepared to lie about my interest in Scientology. I was only prepared to present it less fully' (Wallis, 1976:152). Ultimately Wallis (1977) considered the potential harm of a covert infiltration of Scientology too costly.

3.5 There are four parties that need to be considered with regard to ethical conduct in researching human subjects - the individual participant, the researcher, the larger society, and the researcher's profession (Warwick, 1982: 43). For this reason codes of conduct have been established and are regularly reviewed. The BSA Statement of Ethical Practice states: 'Sociologists, when they carry out research, enter into personal and moral relationships with those they study, be they individuals, households, social groups or corporate entities. Although sociologists, like other researchers are committed to the advancement of knowledge, that goal does not, of itself, provide an entitlement to override the rights of others' $<$ http://www.britsoc.co.uk>.

3.6 Ethical considerations therefore have implications for the way that research is conducted. The most basic choice a participant observer has to make is whether to be covert or overt. An overt researcher role refers to a study in which the status of the researcher is revealed to the participants. Ethical guidelines state:

As far as possible participation in sociological research should be based on the freely given informed consent of those studied. This implies a responsibility on the sociologist to explain in appropriate detail, and in terms meaningful to participants, what the research is about, who is undertaking and financing it, why it is being undertaken, and how it is disseminated and used <http://www.britsoc.co.uk>.

3.7 Therefore, in principle at least, an overt study should protect the ethical integrity of a study particularly in relation to the issue of informed consent. On the other hand a covert researcher role refers to those studies where the status of the researcher remains un-revealed during the fieldwork: a research situation where 'the researcher spends an extended period of time in a particular setting, concealing the fact that he is a researcher and pretending to play some other role. In such a situation the identity of the researcher and knowledge of his work is kept from those who are being studied, who have no knowledge that they are being studied' (Bulmer, 1982a:4).

3.8 It has been increasingly argued that this covert status raises ethical issues because it 'violates the principles of informed consent and may invade the privacy of those being studied'

<http://www.britsoc.co.uk>. Therefore ethical guidelines state that covert research may only be justified in 'certain circumstances' and that 'where informed consent has not been obtained prior to the research it should be obtained ad-hoc' <http://www.britsoc.co.uk>. In general 'the deceptive role is frowned upon and may represent a breach of professional ethical codes' (Fielding, 1993:158) and it is further argued that 'deception is not required in most circumstances' (Fielding, 1993:159). Some argue (Bulmer, 1982a; Warwick, 1982; Shils, 1982) that covert methods are never justified and that it is 'analogous to infiltration by agents provocateurs or spies' (Hammersley and Atkinson, 1995:264). With these guidelines in mind, I decided to adopt an overt researcher role in my research project.

\section{My Own Research}

4.1 For my doctoral thesis, I conducted an ethnographic study of the contemporary spiritual milieu in Scotland. This involved a combination of methods including document and website analysis and interviewing. However it is the participant observation component that will be focused on here as this is the area that has attracted the most controversial debates with regard to ethical conduct and covert practices (Brewer, 2000; Bulmer, 1982a; Laine, 2000). This is not to say, however, that covert practices cannot be found within other ethnographic methodologies.

\section{Participant Observation}

4.2 In gathering data for my doctoral thesis I undertook participant observations in the following settings:

- Rokpa Scotland (for further details see <http://www.samyeling.org.uk >).

Rokpa Scotland refers to the branches of Rokpa International, a Tibetan Buddhist organisation, 
located in Scotland. Within this organisation participant observations took place at several sites. These were in Rokpa Aberdeen at on-going weekly meetings over a one-year period; in Rokpa Dundee at a weekend course; in the central monastery, Samye Ling, at a weekend course and on The Holy Island Project on a seven-day retreat.

- Alternative Health Fairs

Alternative Health Fairs are exhibitions in which a variety of alternative therapists and related practitioners come together to demonstrate their services. In the course of my research, I attended two Body and Soul Health Fairs in Aberdeen and one in Edinburgh, Dundee and Stonehaven (for further details see <http://www.bodyandsoulevents.com>). I also went to The Absolute Health Show ${ }^{[2]}$ in Aberdeen.

- Moondance Tarot Readers Fairs

Moondance Tarot Reader Fairs are events held at the Hilton Hotel, Market Street, Aberdeen. At these events a group of Tarot readers and mediums offer their services to members of the public. This fair occurs three times per year and during the course of my research I attended the fair on three occasions.

4.3 At these various events I participated alongside those involved including participating in religious rituals such as prayers, having my tarot cards read and receiving treatments by alternative therapists. At the outset I felt that my overt researcher role protected the ethical integrity of my study. However the reality of the research field proved somewhat different. It soon became apparent that the ethical issues raised by the covert approach were not entirely resolved and identified a need for a re-evaluation of ethical considerations: 'we should avoid the impression that research ethics are a clear-cut matter, based on a residual, allembracing type of social scientists' natural law' (Holdaway, 1982:79). The BSA cannot provide 'a recipe for resolving ethical choices or dilemmas' (Wiles et al, 2007:1.1). From my own experiences it seems that covert practices are an integral component of all projects, even in overt studies. Therefore the researcher has to negotiate ethical considerations whilst conducting research and these negotiations need to be clearly addressed when writing up.

\section{Reflections on Covert Practices in an Overt Participant-Observation Study}

5.1 The adoption of overt methods of research in my doctoral study did not, in practice, resolve the ethical dilemmas posed by the use of covert methods. My study involved a certain degree of withholding information, manipulation and deception. As such it has to be accepted that my research was at least partially covert and that the adoption of covert practices seemed an essential compromise if the completed research was to be at all fruitful. To illustrate this further, I will focus on three issues - informed consent, the researcher role and field relations.

\section{The Informed-ness of Consent}

5.2 Gaining access to and sustaining a presence in the research field is an important issue in participant observation and there are two stages to this process. 'Getting in' refers to achieving physical access to the research field. In my study this was achieved by emailing the organisers of the three groups and asking permission to attend. However, gaining physical access did not ensure 'getting on', social access (Hornsby-Smith, 1993:53). That is, having gained physical access to the research area I then had to negotiate access to the participants.

5.3 To 'get on' at the Health Shows and the Moondance Tarot fair, I approached stallholders to ask for their co-operation. I was then able to network for further participants. At Rokpa Scotland I was invited to address the group and ask for willing participants to volunteer for an interview. The monk, who ran the group, encouraged group members to co-operate. After addressing the group in Aberdeen, the monk said 'I think we should help him'. This seemed particularly pertinent in an organisation with the motto: 'Helping Where Help is Needed' <http://www.rokpa.org>. Many members of the group were also encouraged to co-operate because I participated alongside them. This was particularly evident on the seven-day retreat on the Holy Island Project. Peter, an Irish janitor on retreat to the Holy Island Project, said:

I think it is really good that you have come to the retreat and are joining in with all the meditations and chanting and stuff. I for one am really impressed that you would do that. I feel much happier talking to someone that is willing to join in and get their hands dirty than someone who just wants to ask questions. Yes, I feel happy to help you.

5.4 In all of the research areas, social access to many of the participants was freely granted. However some of the participants were less open to my enquiries. For example, one woman on a stall for the Brahma Kumaris ${ }^{[3]}$ at the Absolute Health Exhibition said, when I told her of my research, 'I do not think I want to be one of your guinea pigs'. Thus access to the research field may be granted by an authority 
figure, in this case the organiser of the event, but individual participants may not want to be researched (Brewer, 2000:85).

5.5 However gaining the consent of all participants in public events is problematic, if not impossible (Emerson et al, 2007). For example, when I told the group leader at Rokpa Aberdeen that I was a researcher he immediately encouraged me to go on the summer retreat to the Holy Island Project. Once there, I addressed the group and explained that I was a researcher. However some participants were not so consenting. When I went for breakfast the following morning I sat with a group and asked how everyone was doing. Heather, a journalist from the Highlands, replied:

I guess when people see you coming they going running off in the opposite direction. So I suppose you will spend a lot of time chasing after people for interviews but I will tell you now that I won't be participating. As far as I am concerned you do not know how lucky you are to be here! If it were up to me you would not be.

5.6 This posed a dilemma. It would seem that consent is far from straight forward. There is a hierarchy of consent, senior personal or organisers acting as gatekeepers and subordinates being forced to participate (Laine, 2000:34). It may be argued that unwilling participants should not be written about and for most part I tried to avoid them. However, by going out of her way to let me know that she did not want to be part of my research, it was difficult to ignore the importance of what Heather said. It is hard to imagine that many research fields would gain the consent of all those within the field and as such consent is always partial (Emerson et al, 2007). Furthermore, to write out individuals from the research would be an impossible task because their impact on the data direct or indirect would be difficult to isolate. Some may argue that I should have therefore left the research site, as Wallis (1976) did in his research. However, unlike Wallis (1976) I had permission from the gatekeepers to be there and could remain without explicitly lying about my involvement. Besides, so much time and effort had already been invested that leaving would not have been a practical option. If social researchers were to uphold the principle of informed consent to that extent, there would be little room for any ethnographic research to be undertaken. Thus, it would seem, that even in overt research, researchers can only obtain a degree of informed consent as not all participants in public events may wish to comply.

5.7 The principle of informed consent was further compromised in this study because many of the participants did not seem to fully understand the degree to which they were being researched. Most participants did not seem to recognise that my research and record-keeping extended beyond the formal interview process. For example, Sonya, a young artist from Inverness on retreat to the Holy Island Project, declined to be interviewed saying that 'she did not want to be part of my research'. I did nothing to enlighten her. It would have been disruptive to continually issue 'some sociological equivalent of the familiar police caution' (Hammersley and Atkinson, 1995:265) and would have made many of the participants feel very uncomfortable and distrustful (Emerson et al, 2007:357). For this reason, during participant observation, I retired to a more private area to take notes rather than note-take during interactions and this seems to be a typical technique employed by both overt and covert researchers (Fielding, 1993). Therefore, those participants, who were unaware of the ethnographic method, were also unaware of the degree to which they were being observed. So once again, a certain amount of information was withheld which could compromise the principle of informed consent.

5.8 Informed consent also implies that the consenting participant should be made fully aware of the purpose of the research. However, even overt researchers rarely tell all participants everything about their research (Hammersley and Atkinson, 1995:265). Most research will also change direction and may develop in unanticipated ways. Wiles et al (2007:3.1) recognise this problem when they argue that researchers need to provide sufficient information to prospective participants but cannot always guarantee that such information will be sufficient becomes the eventual outcomes of research cannot always be fully anticipated. From the outset of my research I was aware that the direction of my research could change since I had adopted a grounded approach (Glasser and Strauss, 1967). Indeed the focus of my research changed during the research and the writing up period. Therefore it seemed more appropriate to avoid any specifics in explaining my research to the participants.

5.9 Furthermore, it has to be recognised that the majority of the public do not fully understand sociology and in explaining the research focus researchers can find themselves drawn into arguments. For example, when I initially explained my research to participants involved with Rokpa Scotland they were quick to argue that Rokpa could not be compared with the other groups that I was looking at. Before long participants were presuming that I shared their view that health fairs and Tarot groups were 'airy fairy', 'hippy trippy' and 'nothing to do with Rokpa'. To resolve this issue I simplified what I told participants about my research. However, in so doing, it has to be accepted that consent was not fully informed.

5.10 Thus, the 'sound ethical conduct' of the overt researcher is not without compromise. The principle of 
informed consent even in overt participant observation studies would be difficult to uphold in any research situation for a whole variety of reasons: 'Research is a situated business and not open to rationalistic planning. It is in the particular cases of the here and now with participants that ethics are situationally accomplished' (Calvey, 2008:908). In this respect researchers also need to consider the ethical nature of the impressions they gave others whilst participating alongside them.

\section{The Researcher Role: Posing as an Insider}

5.11 In undertaking the role of overt participant observer, the researcher presents himself or herself as an ethnographer and must therefore engage in some form of impression management (Fielding, 1993:158). Impression management refers to the subtle ways that presentations are manipulated in order to achieve the desired response in others (Goffman, 1990). Laine (2000:38) points out 'Access to cultural and interpersonal scripts for performing the roles of observer and participant in a culture or subculture that is not one's own is a necessary part of a successful impression management in the new fieldwork setting'. Thus certain faces may be adopted according to setting and the aims of the researcher. The researcher needs to establish a bond of trust and therefore they need to be 'careful about self representation and demeanour' (Brewer, 2000: 85).

5.12 Laine (2000:34) points out that the notion of wearing a mask is part of everyday social life and this concept is not hard to apply to covert research. For example in Rosenhan's study of mental hospitals researchers presented themselves as patients (Rosenhan, 1982). However it has to be recognised that impression management is also a factor in overt studies (Davies, 2008:62). For example a useful observational tactic can be to present a front of naivety and humility, so that group members feel obligated to explain (Fielding, 1993: 158).

5.13 In my own research, the role of 'acceptable incompetent' (Fielding, 1993: 158) was particularly helpful during my research at Samye Ling and the Holy Island Project because I gained the help of two women who were happy to keep me informed as to what, how and when to do things and answer any questions that I had. In many ways this allowed me, an 'outsider', to pose as an 'insider' and in doing so I could minimise the disruptions that my presence had on the proceedings (Holdaway, 1982). However, on reflection, I have to accept that there was a certain amount of manipulation taking place. Laine (2000:34) recognises this herself when she says 'The dramaturgical approach towards impression management sees research on a continuum of being more or less overt and this makes problematic the establishment of any attempt to establish a cut-off point at which research may be said to be unethical'. Furthermore, Davies (2008:62) points out that some researchers argue that 'the deception in conducting research is part and parcel of the impression management that is integral to social life'.

5.14 The researcher therefore has to accept that whatever the role adopted a degree of deception and participant manipulation takes place. So it is perhaps more useful to see the role of the researcher as cutting the overt-covert continuum (Brewer, 2000). Where to cut the continuum should be a critical decision made by the researcher in response to the research situation including ethical concerns and it needs to be kept in mind that the changing nature of field relations means the continuum will need to be cut in different places at different times and situations within the same study.

\section{Field Relations: Variations in Time and Place}

5.15 Any ethnographic research will contain a degree of covertness, because of the difficulties of revealing your status to all subjects at all times (Fielding, 1993:159). Inherently, fieldwork involves a continuum of 'concealment and disclosure' (Herrera, 1999:331) and the researcher has to decide where the continuum should be cut. Even within a single study the cutting point may vary depending upon location. This is well illustrated in a study by Nancy Scheper-Hughes, an American anthropologist, researching the organstrafficking underworld. In her research she adopted a participant observer role in a variety of fields and cut the overt-covert continuum in relation to the demands of the particular setting (Scheper-Hughes, 2004).

5.16 Like Scheper-Hughes (2004) the overt-covert continuum was cut at different places in my research as field relations developed and changed. For example, during the period I attended Rokpa meetings in Aberdeen I only announced my presence to the group as a whole once. At first my researcher status was discussed by the participants but as the year progressed this declined. Therefore some of the less regular and new attendees may not have been aware of my status and some may have forgotten or thought my research had finished. For example, when Arlene, a constant attendee at Aberdeen meetings, asked if I was going to convert to Buddhism at the concluding ceremony at a workshop in Dundee, was surprised to hear that after almost a year I was still only attending as a researcher. Therefore my impression management and persistent attendance may have paid off in terms of limiting researcher effects but it also raised questions about the effects of time on consent. 
5.17 It must also be realised that the overt/covert balance can have a direct impact on the participation process and research outcomes. For example, during my research on the Holy Island Project, I revealed my researcher status in front of all the participants after a morning meditation. This meant that everyone on the island knew I was a researcher and perceived me as such, above someone interested in Buddhism and participating in the retreat. This was conveyed in various comments by participants. For example, one morning whilst walking in the garden, Stewart said 'Of course being on retreat won't have any effect on you as you are here for different reasons from everyone else'. This contrasted with my experience in Samye Ling. Here I asked for permission from the course administrator to attend as a researcher and I also revealed my status during conversations with some participants encountered. This was possible because unlike Wallis (1976) on the course with the Scientologists, I had the permission of the organisers to attend and the un-dogmatic nature of the teachings meant that I did not have to lie about my beliefs. However, I still did not explain my presence as a researcher to the group as a whole. This meant that the majority of the participants were unaware of my status and even those who knew my status saw me as someone primarily interested in Buddhism, rather than purely as an observer. For example, Andrea, a lawyer from London on retreat, said: 'I know that strictly speaking you are not a Buddhist. But you come here and participate seriously and as long as you take that seriously then you will enjoy the benefits'. This partial covert role provided an interesting contrast with my research in other areas and I therefore decided not to ask people for interviews to maintain this role.

5.18 This partial covert role impacted the research situation. Brewer (2000:99) recognises this kind of impact when he says 'If informants are people and have rights that effect ethical practice, ethnographers are also human and have identities that affect research practice'. During my research in Samye Ling, for most part, I was treated like an insider and as such gained access to the language and dialogue amongst the Buddhist community. Homan argues that some deception is necessary if the researcher is to gain an understanding of in-group dialogue (Homan and Bulmer, 1982:106). Furthermore the withholding of information in this case can be justified because my presence was not harmful to the subjects and their identity was completely concealed. Therefore it could be argued that this methodology was acceptable because it did not 'in any deliberate fashion damage the credibility or reputation of the subject' (Denzin and Erikson, 1982:143). It is also important to note I did not disguise my identity to gain access to fields, which were open to the general public.

5.19 Nonetheless, it has to be accepted that field relations within a study can vary with time and place and have an effect on the overt-ness of a study and impact upon the data collected. Thus, the researcher role in participant observation studies is far from straightforward. In both overt and covert studies codes of ethical conduct can be compromised and what are needed are honest reflections of the research experience, including covert practices in overt studies.

\section{Ethics and the Reflexive Turn: Where to Cut the Continuum}

5.20 Currently social researchers are being invited to contribute to the reflexive turn by reflecting on their research experiences. In particular this draws attention to the place of the researcher in the field under examination and invites the researcher to identify any affects he/she may have had on the research process and the data collected (O'Reilly, 2005:222-223). This generally results in researchers reflecting upon their social backgrounds and attitudes to the research field. However I wish to argue here that it is also important to reflect upon covert/ overt practices for two reasons.

5.21 Firstly the degree of covertness of the researcher role impacts upon the research field and as such should be written into the data so the researcher and subsequent readers can evaluate this impact when considering the validity of the resulting arguments.

5.22 Secondly, in order to engage in ethical debates based on the reality of conducting participant observations, researchers should reflect honestly upon the ethical integrity of their research. Only when frank accounts of situated ethics are published can the true ethical status of a research study be debated. Calvey (2008:905) astutely points out that 'The standard discourse on ethics is abstracted from the doing, which is a mediated and contingent set of practices'. Alternatively, experienced-based ethical debates would allow consequent researchers to make a more informed decision as to where to cut the overt-covert continuum in participant observation studies. After all it is generally recognised that 'Every fieldwork situation brings its own set of ethical problems, many of which are without a solution, but we can learn from the mistakes made by others and their attempts at being accountable' (Laine, 2000:79).

5.23 Importantly I do not want to adopt the utilitarian line (Herrera, 1999:332) and argue that the benefits of research justify deceptive methods of the research. I simply wish to firmly establish that the adoption of an overt role does not resolve the ethical dilemmas associated with covert methods and that most overt studies will include covert practices. Each research environment should be considered on its own merits 
and ethical constraints on the researcher role should be assessed in reference to the specifics of the research situation (Fielding, 1993:170). For example, it may be the case that a more covert approach may be defensible when access is likely to be denied or unreasonable barriers imposed on the overt researcher. Furthermore, Homan argues that 'many of the practices which covert methods are criticised (the betrayal of trust, deception, the invasion of privacy, damage of field relations and the reputation of social research) are neither necessary nor exclusive to covert methods: they are both avoidable in covert research and are probable hazards in explicit investigations' (Homan and Bulmer, 1982:121). Therefore, there is no reason that covert studies should be dismissed carte blanche and it seems unnecessary that a misguided application of the principle of informed consent should immediately restrain a great deal of 'innocuous and unproblematic research' (Christians, 2000:139). What researchers need are guidelines that will allow them to strike the right balance (Wiles et al, 2007) between overt and covert roles. However I agree with Bulmer (1982b:217) when he argues that covert participant observation requires very careful consideration in the light of ethical and practical considerations.

\section{Conclusion}

6.1 The purpose of this paper was to explore the ethical debate surrounding the researcher role in participant observation studies. The current consensus generally views overt research as far more ethical than covert. However, I have demonstrated through reference to my own research that much of the current debate surrounding research ethics is 'abstracted from doing' (Calvey, 2008: 905) and it was consequently argued that honest reflections on experienced-based research ethics is required. In particular I wanted to respond to Calvey's (2008) argument that covert practices often remain unreported in overt research projects by reflecting upon the covert practices in my own overt participant observation study.

6.2 Drawing upon my research experience of the contemporary spiritual milieu in Scotland, I have demonstrated the fallacy in the supposition that overt participant observation reconciles the ethical dilemmas of covert studies. Even in overt research a certain amount of deception, manipulation and withholding of information takes place. This was demonstrated through a discussion of the informed-ness of consent, the ambiguity of the researcher role and the changing nature of field relations. Reflections upon my experience of the research situation revealed that - consent was almost always partial, often given by authority figures on behalf of others; impression management skills were used to reduce researcher presence effects and gain insight to the insider role and the degree of overt-ness varied across time and place. This clearly demonstrated that much of the allegations of ethical misconduct aimed at covert studies can be found in supposedly overt research.

6.3 These reflections also highlighted that covert/overt practices had an impact upon the data collected in my study. In situations where the my researcher role was more towards the covert end of the continuum I was treated as an insider and gathered a different kind of data than when I adopted a more overt role. It was consequently argued that the researcher role should be written into the data so that the reader can place the participant observer within the data.

6.4 Furthermore my experiences could have implications for conducting research in general and I therefore have the responsibility to report my experiences so that others can learn from my experience (Laine, 2000:79). On this basis a call has been made to encourage researchers to reflect honestly on their research experiences in order that the sociological community can begin to make more informed decisions as to ethical conduct. This would help move the discussion of ethics from an abstract debate (Calvey, 2008) to one based on researchers experiences. This may therefore prevent worthwhile, innocuous research being abandoned for fear of reprisals and give researchers the guidelines, rather than regulations, to allow them to strike the right balance when going about their business in the research field (Wiles et al, 2007).

\section{Notes}

1 The contemporary spiritual milieu refers to the overlapping structures between certain types of New Religious Movements, the New Age and secular activities.

2 The Absolute Health Show was a one-off event organised by the Aberdeen Exhibition and Conference Centre in 2007.

3 The Brahma Kumaris is 'a spiritual organization committed to self transformation through meditation and positive thinking' <http://www.bkwsu.com $>$.

$<$ http://www.bkwsu.com > accessed on 13/1/09.

<http://www.bodyandsoulevents.com > accessed on 10/1/09. 
<http://www.britsoc.co.uk> accessed on 14/4/08.

<http://www.mcm.edu> accessed on 13/1/09.

$<$ http://www.rokpa.org > accessed on 14/4/08.

\section{References}

ATKINSON, P, COFFEY, A, DELAMONT, S, LOFLAND, J, and LOFLAND L. (editors) (2007) Handbook of Ethnography, London: Sage.

BREWER, J.D. (2000) Ethnography, Buckingham \& Philadelphia: Open University Press.

BULMER, M. (editor) (1982a) Social Research Ethics: An Examination of the Merits of Covert Participant Observation, London and Basingstoke: The MacMillan Press, pp4-12.

BULMER, M. (1982b) 'The Merits and Demerits of Covert Participant Observation' in M. Bulmer (editor) Social Research Ethics: An Examination of the Merits of Covert Participant Observation, London and Basingstoke: The MacMillan Press, pp217- 251.

CALVEY, D. (2008) 'The Art and Politics of Covert Research', Sociology, Vol.42 No. 5, pp905-918.

CHRISTIANS, C.G. (2000) 'Ethics and Politics in Qualitative Research' in N.K. Denzin and Y.S. Lincoln (editors) Handbook of Qualitative Research, London: Sage, pp133-155.

DAVIES, C.A. (2008) Reflexive Ethnography: A Guide to Researching Selves and Others, London: Routledge.

DENZIN, N and ERIKSON, K. (1982) 'On the Ethics of Disguised Observation: an exchange between Norman Denzin and Kai Erikson' in M. Bulmer (editor) Social Research Ethics: An Examination of the Merits of Covert Participant Observation, London and Basingstoke: The MacMillan Press, pp142- 151.

EMERSON, R.M, FRETZ R.I and SHAW L.L. (2007) 'Participant Observation and Fieldnotes' in P. Atkinson, A. Coffey, S. Delamont, J. Lofland and L. Lofland (editors.) Handbook of Ethnography, London: Sage pp 352-368.

FIELDING N. (1993), 'Ethnography' in N. Gilbert's (editor) Researching Social Life, London: Sage, pp154171.

GLASSER, B.G. and STRAUSS A.L. (1967) The Discovery of Grounded Theory: Strategies for Qualitative Research, Chicago: Aldine.

GOFFMAN, E. (1990) The Presentation of Self in Everyday Life, London: Penguin.

GOFFMAN, E. (1961) Asylums, New York: Doubleday.

HAMMERSLEY, M. and ATKINSON, P. (1995) Ethnography: Principles In Practice, London and New York: Routledge.

HERRERA, C.D. (1999) 'Two Arguments for "Covert Methods” in Social Research', British Journal of Sociology, Vol. 50 (2) pp331-343.

HOLDAWAY, S. (1982) ' 'An Inside Job': a case study of covert research on the police' in M. Bulmer (editor) Social Research Ethics: An Examination of the Merits of Covert Participant Observation, London and Basingstoke: The MacMillan Press, pp59-79.

HOMAN, R. and BULMER, M. (1982) 'On the Merits of Covert Methods: a dialogue' in M. Bulmer (editor) Social Research Ethics: An Examination of the Merits of Covert Participant Observation, London and Basingstoke: The MacMillan Press, pp105-121.

HORNSBY-SMITH, M. (1993) 'Gaining Access' in N. Gilbert's (editor) Researching Social Life, London: Sage, pp52-67.

HUMPHREYS, L. (1970) Tearoom Trade: Impersonal Sex in Public Places, Chicago: Aldine Publications.

LAINE, M. de (2000) Fieldwork, Participation and Practice: Ethics and Dilemmas in Qualitative Research, 
London: Sage.

O'REILY, K. (2005) Ethnographic Methods, London: Routledge.

ROSENHAN, D.L. (1982) 'On Being Sane in Insane Places' in M. Bulmer (editor) Social Research Ethics: An Examination of the Merits of Covert Participant Observation, London and Basingstoke: The MacMillan Press, pp105-121.

SCHEPER-HUGHES, N. (2004) 'Parts Unknown: Undercover Ethnography of the Organs-Trafficking Underworld', Ethnography Vol. 5 (1) pp 29-73.

SHILS, E. (1982) 'Social Inquiry and the Autonomy of the Individual' dialogue' in M. Bulmer (editor) Social Research Ethics: An Examination of the Merits of Covert Participant Observation, London and Basingstoke: The MacMillan Press, pp125-141.

WALLIS, R. (1976) The Road To Total Freedom: A Sociological Analysis of Scientology , London: Heinemann Educational.

WALLIS, R (1977) 'The Moral Career of a Research Project' in C. Bell and H. Newby (editors), Doing Social Research, London: Allen \& Unwin pp149-169.

WARWICK, D.P. (1982) 'Tearoom Trade: Means and Ends in Social Research' in M. Bulmer (editor) Social Research Ethics: An Examination of the Merits of Covert Participant Observation, London and Basingstoke: The MacMillan Press, pp 38-58.

WILES, R, CROW, G, CHARLES, V, and HEATH, S. (2007) 'Informed Consent and the Research Process: Following Rules or Striking Balances?', Sociological Research Online, Vol. 12, Issue 2, $<$ http://www.socresonline.org.uk/12/2/wiles.html>. 